\title{
Correction to: Profile of severely growth-restricted births undelivered at 40 weeks in Western Australia
}

\author{
Helen D. Bailey ${ }^{1}\left[\right.$. Akilew A. Adane ${ }^{1}(1) \cdot$ Brad M. Farrant $^{1} \cdot$ Scott W. White ${ }^{2,3} \cdot$ Pia Hardelid $^{4}$. \\ Carrington C. J. Shepherd ${ }^{1,5}$
}

Published online: 22 July 2020

(c) Springer-Verlag GmbH Germany, part of Springer Nature 2020

\section{Correction to: \\ Archives of Gynecology and Obstetrics \\ (2020) 301:1383-1396 \\ https://doi.org/10.1007/s00404-020-05537-y}

Unfortunately, after publication, we found errors in the extraction of data on gestational diabetes and threatened miscarriage. These errors have now been corrected, and we observed the following differences in our re-run analyses: (1) the association between FGR_37-39 births (small-forgestational-age below the 3rd percentile (FGR) births at 37-39 weeks) and the factors outlined above has changed from a positive direction to null. This requires a change to two rows of Table 2 and one of Table $S 3$ and the text listed below; (2) very minor changes (mostly to the second decimal place) in some of the effect estimates in these tables that pertain to other factors in the multivariable model (data available upon request). None of these corrections change the main message and conclusions of the paper.

Text changes (specific additions underlined).

The original article can be found online at https://doi.org/10.1007/ s00404-020-05537-y.

Helen D. Bailey

Helen.bailey@ telethonkids.org.au

1 Telethon Kids Institute, The University of Western Australia, Nedlands, WA, Australia

2 Division of Obstetrics and Gynaecology, The University of Western Australia, Nedlands, WA, Australia

3 Maternal Fetal Medicine Service, King Edward Memorial Hospital, Subiaco, WA, Australia

4 Population, Policy and Practice Programme, Great Ormond Street Institute of Child Health, University College London, London, UK

5 Ngangk Yira Research Centre for Aboriginal Health \& Social Equity, Murdoch University, Murdoch, WA, Australia
1. Results section: Risk factors for FGR births; 2nd paragraph, sentences 1 and 2: Having gestational diabetes or a threatened miscarriage was negatively associated with an FGR_40 birth (FGR undelivered at 40 weeks) but not associated with a FGR_37-39 birth (LHT $p<0.01,0.03$, respectively) (Table 2). The following factors were only positively associated with FGR_37-39 births: having a major congenital anomaly, a mother aged $>34$ years, experiencing a pregnancy complication (pre-eclampsia, gestational hypertension) and living in the most disadvantaged area (tertile).

2. Results section: Paragraph prior to birth outcomes, sentence 1: Compared with mothers who had a non-SGA 37 + birth, mothers who had a FGR_40 or FGR_37-39 birth were more likely to have at least one major or three minor RCOG risk factors for SGA births ${ }^{1}$ (OR 1.35, 95\% CI $1.15,1.59$ and $1.96,95 \%$ CI $1.73,2.23$, respectively, LHT $p<0.01$ ) (results not otherwise shown), although these risk factors were prevalent in all three groups $(40.1 \%, 46.8 \%$ and $57.0 \%$ of Not SGA $37+$ (Births at 37 or later weeks' gestation not SGA), FGR_40 and FGR_37-39 births, respectively) (Table S3).

3. Discussion: Last paragraph before Conclusion: $3^{\text {rd }}$ sentence: For example, it appears that pregnancies complicated with gestational diabetes are being carefully monitored, so are rarely left undelivered at 40 weeks if there are any concerns about fetal growth, leading to a negative association with FGR_40 births but not with FGR_37-39 births. 


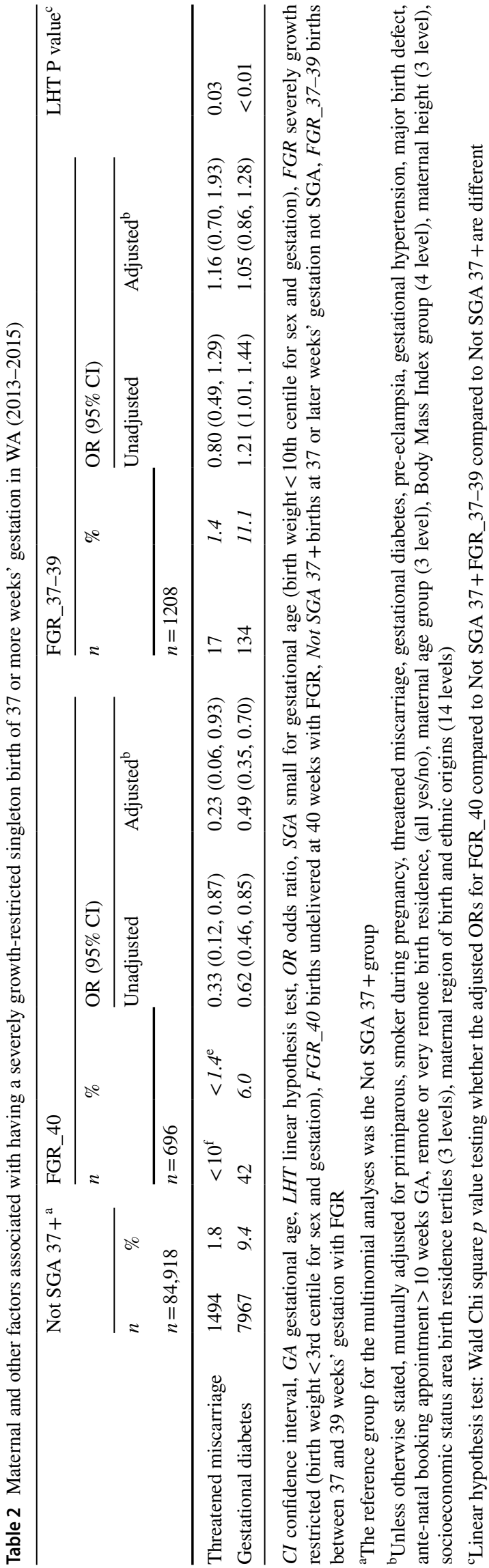

Table S3 Prevalence of RCOG minor and major risk factors for SGA

\begin{tabular}{|c|c|c|c|c|c|c|c|}
\hline \multirow[t]{2}{*}{$\begin{array}{l}\text { SGA risk } \\
\text { factors }\end{array}$} & \multicolumn{2}{|c|}{$\begin{array}{l}\text { FGR_40 } \\
(N=696)\end{array}$} & \multicolumn{2}{|c|}{$\begin{array}{l}\text { FGR_37- } \\
39 \\
(n=1,208)\end{array}$} & \multicolumn{2}{|c|}{$\begin{array}{l}\text { Not SGA } \\
37+(N \\
=84,918)\end{array}$} & \multirow{2}{*}{$\begin{array}{l}\text { Overall } \\
\text { missing } \\
\text { data } \\
\%\end{array}$} \\
\hline & $n$ & $\%$ & $\mathrm{n}$ & $\%$ & $\mathrm{n}$ & $\%$ & \\
\hline $\begin{array}{l}\text { At least } 1 \\
\text { major or } 3 \\
\text { minor risk } \\
\text { factors }\end{array}$ & 326 & 46.8 & 688 & 57.0 & 34,052 & 40.1 & \\
\hline $\begin{array}{l}\text { Major risk } \\
\text { factors }\end{array}$ & & & & & & & \\
\hline $\begin{array}{l}\text { Pregnancy } \\
\text { complica- } \\
\text { tions/devel- } \\
\text { opments }\end{array}$ & & & & & & & \\
\hline $\begin{array}{l}\text { Threatened } \\
\text { miscarriage }\end{array}$ & $<10^{\mathrm{b}}$ & $<1.4^{\mathrm{b}}$ & 17 & 1.4 & 1,494 & 1.8 & 0.0 \\
\hline
\end{tabular}

SGA small-for-gestational-age, ROCG Royal College of Obstetricians and Gynaecologists, FGR_40 births undelivered at 40 weeks with FGR, Not SGA 37 + births at 37 or later weeks' gestation not SGA, FGR_37-39 Births between 37-39 weeks' gestation with FGR

${ }^{a}$ Royal College of Obstetricians and Gynaecologists. The Investigation and Management of the Small-for-Gestational-Age Fetus. Green-top Guideline No. 31, 2nd Edition. Royal College of Obstetricians and Gynaecologists.2013

${ }^{\mathrm{b}}$ Exact numbers and percentages not given for cells with $n=1-9$

\section{Reference}

1. Royal College of Obstetricians and Gynaecologists (2014) The Investigation and Management of the Small-for-Gestational-Age Fetus. Green-top Guideline No. 31, 2nd edn. Royal College of Obstetricians and Gynaecologists

Publisher's Note Springer Nature remains neutral with regard to jurisdictional claims in published maps and institutional affiliations. 